\title{
NETWORKAPPROACH BASED ON COMMUNITY FORESTRY MANAGEMENT: STAKEHOLDERS MANAGEMENT METHODOLOGY FOR FORESTRY GOVERNANCE OF PERUVIAN AMAZON
}

Received on: 09/10/2018 Approved on: 01/11/2018

Marta Tostes ${ }^{1}$

Claudia Motta²

\begin{abstract}
The study aims to develop the governance issue in the Amazon as a means to access international markets. The articulation of organizations involved in Community Forest Management promotion was measured on an experience in Aguaytía Peru, in order to identify alliances that allow access to funds for natural resources management. The first methodology step was the mapping by saturation of stakeholders with their classification and prioritization for field work. The second step was to identify relationships through the link matrix. This process included secondary sources review and fieldwork where interviews, observation and attendance to key events were performed. With this information, the organizations network was constructed having stakeholders as nodes and relationships as links. Gephi software was used as support to facilitate the governance evaluation indicators construction process. As a research result, the most relevant forest governance stakeholders in Aguaytía were identified. Likewise, the network methodology evidenced that although formal power rests on public organizations, civil society organizations that work more closely with the population, exert real power.
\end{abstract}

Keywords: Forest Governance, Sustainable Development, Community Forest Management, Network Approach, Gephi

\footnotetext{
1 Graduated in Economic Science from the Federal University of Rio de Janeiro, UFR, master in Economic Science from the UFR and doctorate degree in Economis Science from Sevilla University: Sevilla, Andalucía. E-mail: mtostes@pucp.edu.pe

2 Graduated in Management from the Pontifical Catholic University of Peru, PUCP and principal researcher at EXCEDESA, Lima, Perú.

E-mail: claudia.motta@pucp.pe
} 


\section{INTRODUCTION}

Climate change is a reality that generates international level concern (IPCC, 2015) and is considered "the most complex global economic and public policy problem that humanity has faced" (Sachs, 2014, pág. 460). Forests, as natural resource and habitat for many flora and fauna species, are one of the most relevant and necessary topics to deal with (MINAM, 2016). It is necessary to remember that $30 \%$ of the earth's surface is occupied by forests, which represents four billion hectares (FAO, 2010). Its importance relies not only on oxygen production, but also because it is one of the largest carbon sinks that capture greenhouse gases produced by human activity (Lima COP20, 2014). Therefore, its conservation is a decisive factor in mitigation and adaptation strategies to face climate change.

Peru is one of the countries with the largest natural forests area within its territory, approximately 60\% (Programa Nacional de Conservación de Bosques para la Mitigación del Cambio Climático, 2018). Peru is the second country with the greatest forests extension in Latin America and is ninth worldwide (Schwarts, 2004). Although to have flora and fauna diversity is a great advantage for the country, it is also a great responsibility and challenge to preserve it (MINAM, 2015).

On the other hand, forests are also life source for communities and small villages that extract forest resources to subsist (Malleux Orjeda, 2015). In this context, community forest management has emerged as a population response to the forest degradation problem (Nalvarte Armas, 2015). This activity has generated different stakeholders involvement that contribute to sustainable management of resources and, at the same time, promote that communities comply with regulations regarding access to international markets and obtain better prices (Sabogal, de Jong, Pokorny, \& Louman, 2008).

The problem of this research derives from understanding how Peruvian Amazon governance is organized, in a context where natural resources must be protected, but at the same time they are subsistence source for different communities. The study seeks to construct and analyze stakeholder networks, to identify articulation arrangement of forest governance involved stakeholders. The purpose is to ensure that indigenous communities comply with necessary requirements and certifications to access international markets. To this end, articulation levels of several organizations community forest management involved in Aguaytía basin were measured. The existing alliances between organizations and population were identified to improve natural resources management.

\section{THEORETICAL FRAMEWORK}

To understand the problem and methodology of this research, a theoretical support is necessary to develop the main issues around which the study revolves. First, the forest governance literature is reviewed. To this end, the first step was to understand the term's definition and then apply it to environmental and forestry scope. For Andrade,

[...] governance implies a sense of direction, of the government's action capacity [...] a regulation system resulting from social, political and economic stakeholders intervention efforts in governing activity and in the definition of government rules and instruments (Andrade, 2011, pág. 19).

Kooiman, describes modern society governance as a mix of efforts from the government and from all types of socio-political, public and private stakeholders, which takes place at different levels and in different ways (Jan, 2005). Therefore, it is a fact that governance is built on the basis of different stakeholders' confluence. 
With regard to environment, the relationship between environmental concerns and both poverty and development indicators was reaffirmed during the United Nations Conference on Environment and Development (UNCED) held in Rio de Janeiro in 1992. On this basis, environmental issues inclusion in the countries' policies and development plans was considered. Thus, Agenda 21 emerges as a plan that includes commitments in various subjects to achieve development in the 21st Century (IARNA, 2009, pág. 11). The governments took over and assumed the task of including in their public policies measures to promote control and reduction of environmental crisis. In consequence, Andrade mentions that "the need arises to have legal frameworks to regulate and control natural resources exploitation to avoid the increase of environmental impacts, of social conflicts and ecosystems degradation" (Andrade, 2011, pág. 20). Therefore, environmental governance starts to be relevant for different stakeholders, including non-governmental (NGOs) and international organizations. These social stakeholders have been increasing their importance given the impact they generate in contrast to other traditional stakeholders. (Bridge \& Perreault, 2008).

In light of this, current climate issues require environmental governance that can provide answers to an international problem and that can guarantee natural resources conservation. As stated earlier, this refers to the regulatory framework and as such, proposes environmental policies that look for biodiversity conservation while responding to population needs. Accordingly, environmental governance seeks to ensure habitats and nature conservation and, at this point, forests become one of the main concerns within protection initiatives (Motta, 2016).

Within this context, it is important to consider that environmental governance, as mentioned, does not depend on a single stakeholder or area, but rather on different stakeholders that in larger or smaller proportion influence the territory where they are located. This exerted real power has two characteristics: first, they are institutions that carry out actions according to their particular interests and, second, they are actions that are carried out outside the traditional legal framework (Aceves, 2013). Accordingly, to study forest governance of a geographical area is necessary to know not only the measures and actions that come from the governments' formal power, but also the real power exerted by institutions that are generating impact in the communities. For this purpose, necessary steps to study forest governance are stakeholders (private, public and civil society) identification and relationships analysis.

With regard to environmental governance regulation towards exports to ensure international quality and sustainable development standards, "intersectional collaboration, consistent policies and better governance are required; trade of forest products and services, and good forest management can support each other" (Mersmann, 2004/4). In 2003, the European Commission adopted the Action Plan for the Application of Forest Law Enforcement Governance and Trade (FLEGT) to fight trade from illegal forest wood logging (European Forest Institute, 2008). This had influence on commercial agreements established with other countries and regions, which implied an effort to propose a clear institutional arrangement to comply with the requested standards.

For years, Peruvian forestry policy has not considered long-term forest management, even though Peru is one of the countries with a considerable forest extension. In consequence, community forest management emerges as an interesting option because it represents a rural livelihood element that can be a working approach to wood production and to economic benefits for forest living people. (Gaviria, 2010). Native communities are evident protagonists because their territories house all kinds of natural resources. As Nalvarte (2015) says, "around 12 million hectares of Peruvian forest territory is found on lands owned by native communities (NC)." Although it is a considerable amount, only recently Government has included population participation in forest policies. 
Until recently, Peruvian policies did not consider indigenous populations decision-making. However, that trend is already reverting. An example is the National System of Protected Natural Areas (PNA), where local communities have assumed an important planning role. This way within public administration, doors have been opened to other civic-social organizations, as is the case of PNA Management Committees that support 31 protected natural areas throughout the country (Leon Morales, 2007).

Likewise, it is important to consider the impact on communities generated by community forest management.

[...] forest management has positively contributed to: i) community members' capacities development, ii) communal and family infrastructure improvement, iii) sustainable use of resources, iv) strengthening of community member's commitment to conservation and its communal organization; and v) economic income increase of Economic Productive Organization (OEP) member families (Nalvarte Armas, 2015, pág. 5).

In practice, the community member, in the short term, is not aware of this effect because what he sees is his final income reduction. At this point, the role of other organizations becomes relevant to approximate the community to international markets that could not otherwise be accessed. Due to market regulations for products export, it is necessary to comply with certifications both in the wood and other biodiversity products market.

That is why, for community forest management to be effective and to constitute a community's sustainable income source, different organizations have been working not only to protect natural resources, but also for them to be responsibly and beneficially used in favor of the communities that inhabit them.

Therefore, in this study networks approach is understood as an analysis method that allows understanding of how this institutional arrangement is effectively defined to facilitate communities' sustainable use, while simultaneously guaranteeing forests conservation. This way, Gutiérrez (2001) points out that society can be thought in terms of structures, as different stakeholders' relationships. All the links or relationships form networks. From these constructions, it is possible to analyze both the group and each stakeholder in relation to the network.

The first step to build these structures is stakeholders mapping, to identify the most relevant stakeholders that have some interest in the study area (Acuña, 2012). Once they have been identified, a categorization is made according to the influence or importance degree they have. Then a network that allows its graphical appreciation is constructed (PMI, 2013). Thus, these networks show the different relationships that exist between stakeholders.

For that matter, networks are constituted by two elements: stakeholders and relationships between them. In the network, stakeholders are represented by points or nodes, while relationships are the lines or links between them (Motta, 2016). Once the network is assembled, stakeholders' relationships and characteristics and their articulation are analyzed. "Network analysis describes and studies the relational structures that arise when different organizations or individuals interact, communicate, coincide, collaborate, etc., through various processes or agreements" (Sanz Menéndez, 2003, pág. 3). These structures are evaluated to come to conclusions about a specific stakeholder or about the network as a whole. In this research, network construction and its analysis will aim to study Amazon governance in a specific geographic area, where international cooperation is promoting, through local stakeholders, the standards introduction for certified wood commercialization. 


\section{METHODOLOGY}

The methodology was based on network analysis of a community forestry project funded by an international agency, USAID. The project was called "Strengthening social capital and its sustainable forest management articulation for alternative development process of Aguaytía basin, Ucayali Region"; it started in 2014 and concluded in 2017. This project was chosen because the organization in charge, AIDER (Association for Integral Research and Development), had already been working on community forestry in Aguaytía area, especially promoting certified wood attainment for export. This particular project has connected with different stakeholders, such as villages and native communities, working very closely in improving their wood extraction capacities. The importance of forest management within Ucayali and especially of wood sector non-traditional exports relies on its fairly wide international market. Ucayali exports to countries such as China, Mexico, United States, Dominican Republic and France among others. In 2013 it represented 95.39\% of USD total exported amount (MRO-PROMPERÚ, 2013). Therefore, certified wood export is one of the activities that generate region's greatest income. That is why community forestry projects concentrate efforts to maintain and increase the amount of wood in the international market.

Such is the case of AIDER, who started working with community forestry projects in 2000, achieving in 2005 that five native communities applied to forest certification according to FSC standard. This process evidenced existing barriers to achieve quantity and quality demanded by market. To address these requirements, a Wood Collection Center was installed and a transformation plant was set up with the aim of collecting, transforming and marketing $100 \%$ FSC certified wood. With this great advance, the Chain of Custody certificate was obtained the following year. Preparations started in 2015 to make a first pilot export with the goal of projecting sales to international market. In this process two new difficulties were identified: direct export contact establishment and high client's distrust about compliance of native communities. Therefore, AIDER decided to contact directly and take the intermediation role between the company and the communities, achieving a satisfactory agreement for both parties. In February 2016 the export was performed; 23,000 sawn wood board feet were sent from Pucallpa (Ucayali) to the company's plant in Lima to give added value and obtain a first quality final product for export (AIDER, 2018). This experience reinforces that existing organizations exercise forest governance in specific territories to obtain better living conditions for communities and villages from a livelihood resource such as wood.

Methodology was divided into three parts for this research. As first step, stakeholders mapping by saturation was done; it included their categorization and field work prioritization. 
Table 1. Stakeholders mapping and categorization

\begin{tabular}{|c|c|}
\hline Organization type & Name \\
\hline \multirow{5}{*}{ Native communities } & Puerto Nuevo \\
\hline & Sinchi Roca \\
\hline & Puerto Azul \\
\hline & Yamino \\
\hline & Mariscal Cáceres \\
\hline \multirow{6}{*}{ Small villages } & Nuevo Ucayali \\
\hline & Norberth de Alto Uruya \\
\hline & Nuevo Satipo \\
\hline & Virgen del Carmen \\
\hline & La Unión \\
\hline & San Juan Bautista \\
\hline \multirow{4}{*}{ Native organizations } & Padre Abad Technical Cocoa Association (ACATPA by its Spanish acronym) \\
\hline & Cocoa Peru Alliance \\
\hline & ORAU \\
\hline & FENACOCA \\
\hline \multirow{4}{*}{ Social organizations } & AIDER \\
\hline & CNF \\
\hline & CIMA \\
\hline & IBC \\
\hline \multirow{15}{*}{ Public organizations } & Padre Abad District Municipality \\
\hline & Irazola District Municipality \\
\hline & Ucayali Regional Government - Natural Resource Management \\
\hline & Ucayali Regional Government - Native Affairs Management \\
\hline & Native Communities Development Regional Institute \\
\hline & Padre Abad Provincial Municipality - Aguaytía \\
\hline & Ucayali National University (UNU by its Spanish acronym) \\
\hline & $\begin{array}{l}\text { Forest Resources and Wild Fauna Supervision Authority (OSINFOR by its Span- } \\
\text { ish acronym) }\end{array}$ \\
\hline & $\begin{array}{l}\begin{array}{l}\text { Forest Management and Wild Fauna Department (DGFFS by its Spanish acro- } \\
\text { nym) }\end{array} \\
\end{array}$ \\
\hline & $\begin{array}{l}\text { Information and Education Center for Drug Abuse Prevention (CEDRO by its } \\
\text { Spanish acronym) }\end{array}$ \\
\hline & National Commission for Development and Life without Drugs- DEVIDA \\
\hline & Agriculture and Irrigation Ministry (MINAGRI by its Spanish acronym) \\
\hline & Informal Property Formalization Agency (COFOPRI by its Spanish acronym) \\
\hline & US Agency for International Development (USAID) \\
\hline & United Nations (ONU by its Spanish acronym) \\
\hline
\end{tabular}

Source: to include after revision.

Likewise, based on expert opinions, the interest-power matrix of stakeholders' characteristics in relation to community forest management was elaborated. This matrix shows that although communities and small villages are essential for forestry activity, they do not have much power over it because they lack technical knowledge or marketing channels. It also shows that public institutions are located in the upper part of the graph, since their formal power is high. This point will be analyzed later with the obtained results. 
Table 2. Interest-power matrix of MFC in Aguaytía basin

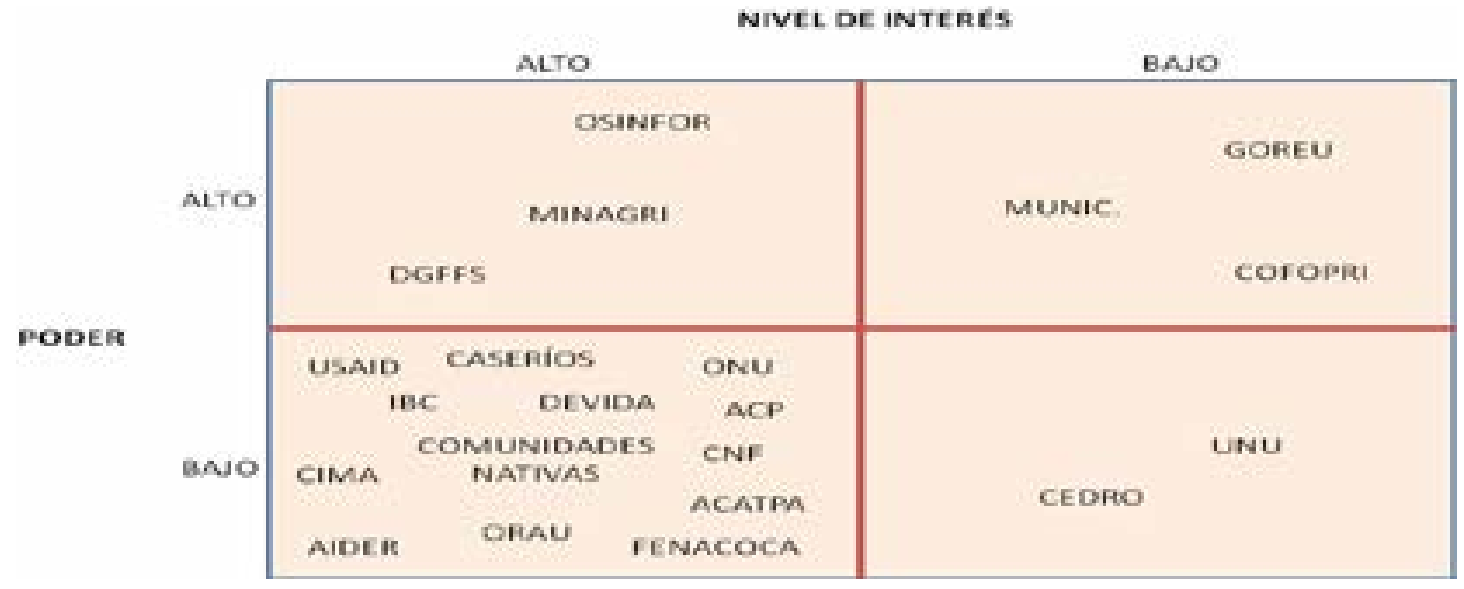

Source: to include after revision.

The second step consisted in relationships identification through a links matrix where stakeholders' crossover and its evidence was recorded for each one. To get a complete picture as first step it was necessary to identify the links. To this end, a web search was made to obtain all news, documents or events that included at least two identified stakeholders. Thus, different relationship types could be found, such as financial support, technical assistance, public hearing, training, congress, prior consultation, complaint, mediation, discussion table, work table, news, request, program, project, meeting, sanction and workshop (Motta, 2016). Fieldwork complemented this process, where interviews, observation and attendance to key events were done. As sample of the followed process, the first four identified relationships are presented.

To perform this analysis, some computer tools facilitate information entry through matrices, and graph construction. This software builds the network and helps obtain measurements according to what is being analyzed. Although at the time the research was conducted the most used computer tool was UCINET, GEPHI software use was decided because it facilitates incorporating more features about the links.

Accordingly, the third step consisted in network conformation using Gephi software as support. Thus, collected information from the link matrix was entered and the organizations network was constructed following the Cerrillo (2005) approach, using stakeholders as nodes and relationships as links.

Table 3. Coding model of the Link Matrix

\begin{tabular}{|c|c|c|c|}
\hline Code & $\begin{array}{c}\text { Relationship } \\
\text { type }\end{array}$ & Source & Description \\
\hline A01 & Penalty & www.inforegion.pe & $\begin{array}{c}\text { Communities are observed for mishandling of their } \\
\text { operational plans }\end{array}$ \\
\hline A02 & $\begin{array}{c}\text { Discussion } \\
\text { table }\end{array}$ & www.inforegion.pe & $\begin{array}{c}\text { Participation in discussion table to strengthen indige- } \\
\text { nous leaders capacities in community forest manage- } \\
\text { ment }\end{array}$ \\
\hline A04 & Project & $\begin{array}{c}\text { www.gacetaucayalina. } \\
\text { com }\end{array}$ & $\begin{array}{c}\text { Reforestation at UNU within the community forestry } \\
\text { and social capital project framework }\end{array}$ \\
\hline www.aider.com.pe & $\begin{array}{c}\text { Joint Project "Social Capital Strengthening and its for- } \\
\text { est management articulation for alternative develop- } \\
\text { ment process of Aguaytía basin, Ucayali Region" }\end{array}$ \\
\hline
\end{tabular}

Source: to include after revision. 


\section{RESULTS ANALYSIS AND DISCUSSION}

To have a significant stakeholders' network that works on community forest management is important because, as already mentioned, wood is one of the relevant export products. However, wood sector has some shortcomings such as lack of adequate infrastructure, few business organizations, low integration, and rather incipient technological development (MINCETUR, 2005).

The complete result can be seen below. In this graphic, colors strength reflects stakeholders' quantity with which the node is connected.

As can be observed, the following organizations have the strongest colors: AIDER (53 links), DEVIDA (41 links), FENACOCA (40 links), ORAU (37 links) and IBC (46 links). These results show that the aforementioned organizations are the better connected in Aguaytía basin and therefore, have greater presence. However, if the influence is positive or negative cannot be precisely determined. Besides AIDER, organization who set up the network, there are other organizations not specifically from the public sector. DEVIDA is an organization that, although is government dependent, works autonomously and even provides budget to municipalities and regional governments. This organization is well positioned, because it has relationship with government agencies and has been working in the area to change coca cropping to cocoa.

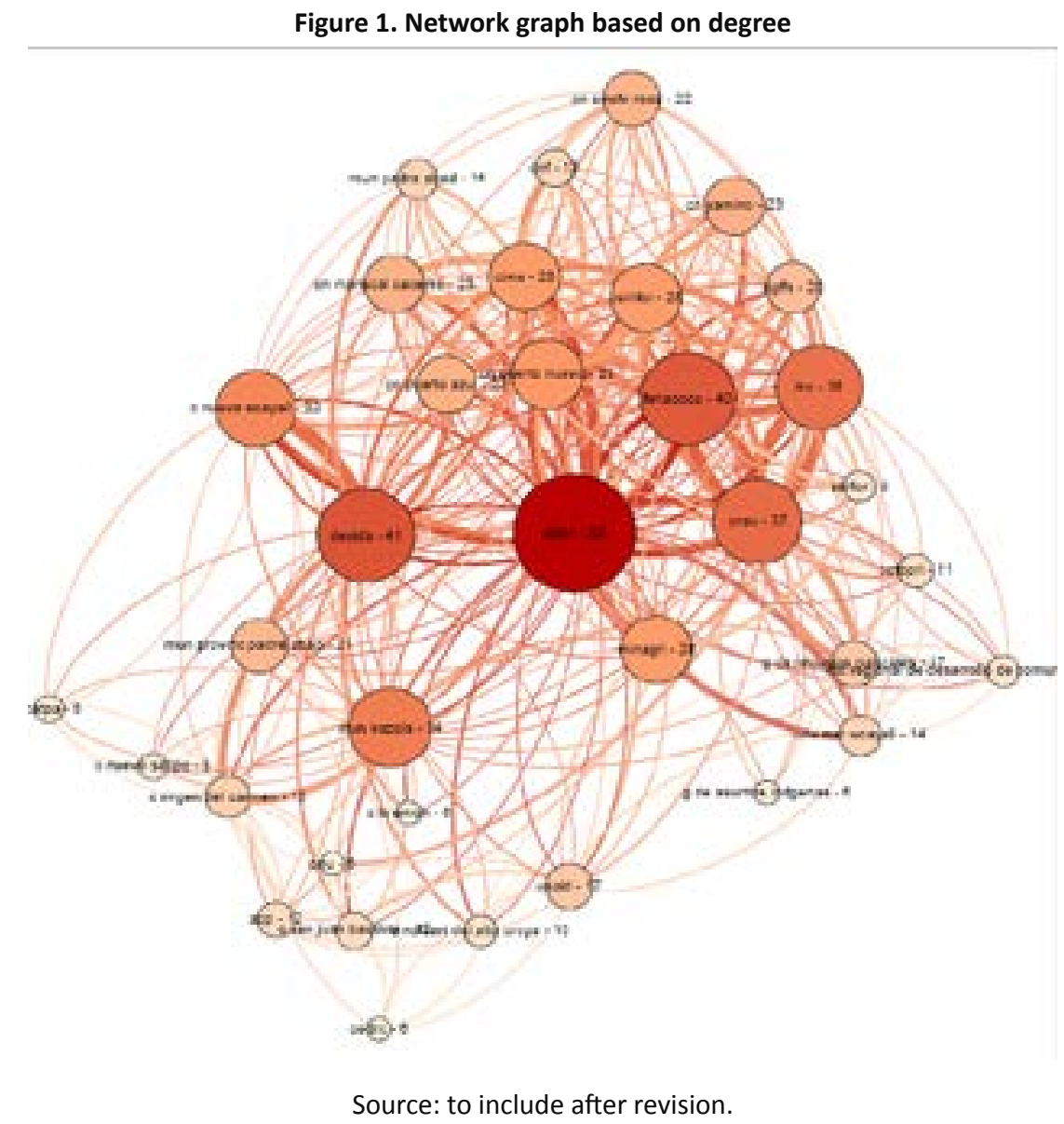

FENACOCA and ORAU are organizations that group, in one case, native Cacataibo communities and in the second, all Ucayali region located native communities. Finally, IBC is a NGDO dedicated to specific issues such as land management, physical sanitation, conflict resolution and 
cacataibo landscape management. It is currently working with native communities and coordinating with government agencies.

Although these results show number of organizations' relationships, a finer analysis is given when work is based on Intermediation measure. This measure evaluates a node's intermediation capacity in relation to two other network nodes. The resulting graph is shown below.

Figure 2. Network graph based on intermediation degree

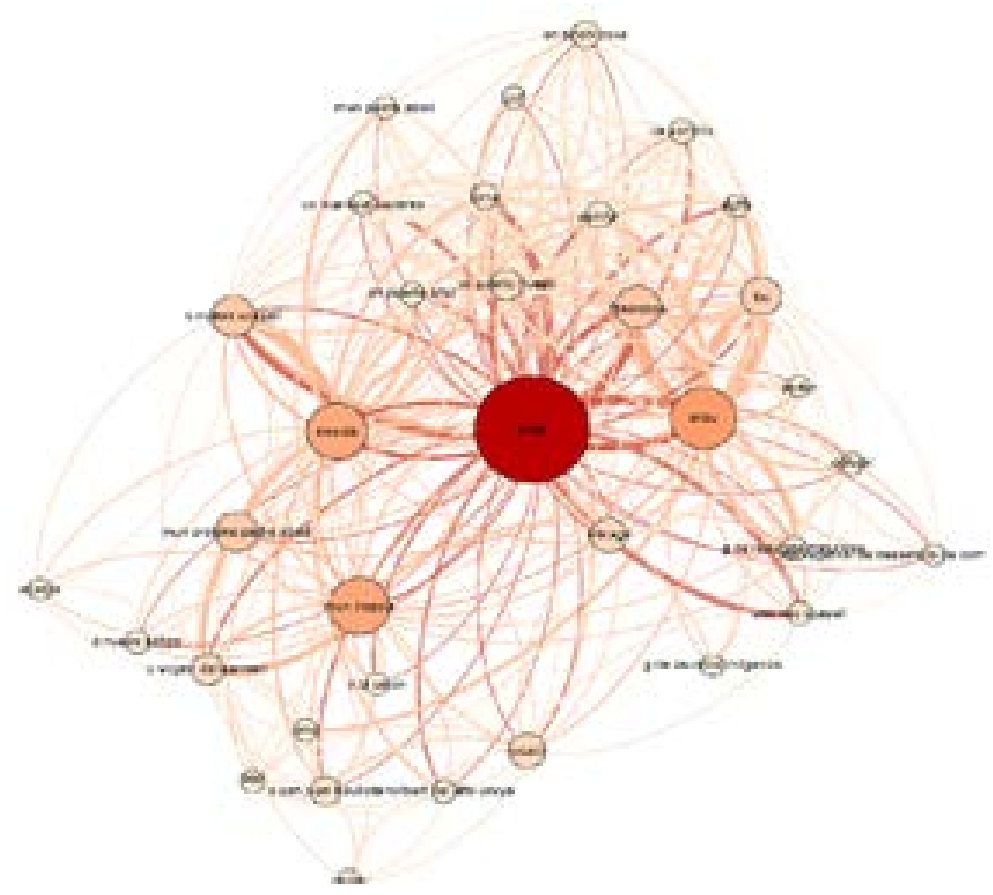

Source: to include after revision.

The graph shows at first glance that AIDER leads the network. Below is the table with the first six results arranged by intermediation degree from highest to lowest.

Table 4. Intermediation degree

\begin{tabular}{|c|c|c|}
\hline ID & LABEL & BETWEENEESS \\
\hline 14 & Aider & 233.0 \\
\hline 12 & Orau & 109.2 \\
\hline 21 & munirazola & 96.8 \\
\hline 31 & Devida & 94.1 \\
\hline 13 & Fenacoca & 55.8 \\
\hline 11 & c nuevo Ucayali & 51.7 \\
\hline
\end{tabular}

AIDER presents the highest intermediation degree, meaning that several nodes are connected or pass through this stakeholder to reach another. This is known as geodesic path, the shortest route to reach another node. It is important to assume this role because it allows a stakeholder to relate to another that in normal circumstances would not be within its reach. Stakeholders that present high intermediation level facilitate this dynamic and act as bridges between two others, revealing potential for communication control between stakeholders. AIDER's high intermediation degree is due to its presence in Ucayali region. The various projects it has 
been implementing, has given the opportunity to contact most stakeholders around the MFC. This has proven an opportunity for AIDER as organization and an advantage for the communities and small villages with which it works.

Other important stakeholders are FENACOCA and ORAU indigenous organizations. Their role is very important as connectors or intermediaries between the indigenous communities they represent and Government agencies or other organizations initiatives.

Irazola Municipality is well located in the network, thus, it also has high intermediation degree, so it would be able to attend and link stakeholders. However, in the relations weight analysis result, this organization and in general public sector ones are not reliable for communities and small villages. Although municipalities are stakeholders that have or should have high intermediation level, this capacity is not fully exploited.

Also, DEVIDA is an organization that plays an important role in the network. Like AIDER, this organization acts as bridge to public services. Mr. David Malpartida, DEVIDA representative, mentions that they attempt to bring government to communities and small villages.

\section{CONCLUSIONS}

As consequence of the research, two main results were obtained. First, network approach has allowed forest governance analysis in Aguaytía basin, studying and analyzing different stakeholders' relationships. Likewise, it has been possible to identify most relevant stakeholders for forest governance in Aguaytía and those with highest intermediation level to connect communities and small villages with international markets.

Network approach is a very useful methodology because it evidences that governance does not depend on a single entity or only upon public sector as might be expected. On the other hand, for adequate governance with management plans that allow access to global financing mechanisms, it is necessary different stakeholders' synergies. Therefore, to achieve governance aimed at resource management improvement through community forest management, it is necessary to understand the organizations' networks that become effective with joint and coordinated work.

In addition, these results show that although formal forest governance power rests on public organizations, real power is exerted by other organizations such as AIDER, DEVIDA, CIMA, among others, that have more access to communities and small villages.

\section{BIBLIOGRAPHY}

Aceves, F. (2013). Poderes fácticos, comunicación y gobernabilidad: un acercamiento conceptual. Revista Mexicana de Ciencias Políticas y Sociales, 269-280.

Acuña, A. (2012). La gestión de los stakeholders: análisis de los diferentes modelos; Encuentro Regional Zona Sur. Buenos Aires: ADENAG.

AIDER. (2018). Experiencia piloto de axportación de madera certificada de CCNN en alianza con la empresa privada. Pucallpa.

Andrade, K. (2011). Gobernanza Ambiental en Perú y Bolivia: Tres dimensiones de gobernanza: recursos naturales, conservación en áreas protegidas y comunidades indígenas. Quito: FLACSO. 
Bridge, G., \& Perreault, T. (2008). Environmental Governance. In N. Castree, \& D. Demeritt, A Companion to Environmental Geography (pp. 475-497). Black Well Publishing.

Cerrillo, A. (2005). La Gobernanza Hoy: Introducción. In A. Cerrillo, La Gobernanza Hoy: 10 texts de referencia (pp. 11-36). Madrid: INAP.

European Forest Institute. (2008). Aplicación de leyes, gobernanza y comercio forestal, el enfoque de la Unión Europea; EFI enfoque de políticas 2. Finlandia: Comisión Europea.

FAO. (2010). Evaluación de los recursos forestales mundiales 2010. Roma.

Gaviria, A. (2010). Participación de las Comunidades Nativas en la Conservación y Gestión Sostenible de los Bosques Tropicales de la Amazonía Peruana. Lima: Centro para el Desarrollo del Indígena Amazónico (CEDIA).

IARNA. (2009). Cuenta Integrada del Bosque (CIB). Guatemala: IARNA-URL.

IPCC. (2015). Cambio Climático 2014: Informe de Síntesis. Genève 2.

Jan, K. (2005). Governing as Governance. Londres: SAGE Publications.

Leon Morales, F. (2007). El Aporte de las Áreas Naturales Protegidas a la Economía Nacional. Lima: INRENA.

Lima COP20. (2014). COP20 - Sección Bosques. Retrieved from http://www.cop20.pe/seccion/ bosques/

Malleux Orjeda, J. (2015). Manejo de Bosques con Participación de Poblaciones indígenas en la Región Loreto; Prouestas de Políticas para los Gobiernos Regionales, 2015-2018. Lima: CIES.

Martin Gutierrez. (2001). Mapas Sociales: método y ejemplos prácticos. Diálogos: Educación y formación de personas adultas, 26-36.

Mersmann, C. (2004/4). Los vínculos entre el comercio y la ordenación forestal sostenible: una visión de conjunto. Revista internacional de silvicultura e industrias forestales, 55(219), 3-10.

MINAM. (2015). Guía de inventario de la flora y vegetación. Lima.

MINAM. (2016). Estrategia Nacional sobre Bosques y Cambio Climático. Lima.

MINCETUR. (2005). Plan Estratégico Regional Exportador. Región Ucayali. MINCETU-USAID.

Motta, C. (2016). El rol de las ONGD en el fortalecimiento del capital social para mejorar el manejo forestal comunitario: El caso de AIDER en la cuenca de Aguaytía. Lima: Pontificia Universidad Católica del Perú.

Motta, C., \& Tostes, M. (2016). Metodología basada en el enfoque de redes y uso del software Gephi: el caso de AIDER en el fortalecimiento del capital social para el Manejo Forestal Comunitario en la cuenca de Aguaytía, Ucayali, Perú. Revista Ibérica de Sistemas y Tecnologías de Información, 131-144.

MRO-PROMPERÚ. (2013). Avance Regiones. Ficha Ucayali.

Nalvarte Armas, J. (2015). Manejo Forestal Comunitario para mitigar cambio climátio: La 
experiencia de la Comunidad Nativa Callería, Ucayali - Perú. Lima: Asociación para la Investigación y Desarrollo Integral - AIDER.

PMI. (2013). Project Management Bod of Knowledge. Pensilvania.

Programa Nacional de Conservación de Bosques para la Mitigación del Cambio Climático. (2018). Programa Nacional de Conservación de Bosques. Retrieved 07 23, 2018, from http://www. bosques.gob.pe/peru-pais-de-bosques

Sabogal, C., de Jong, W., Pokorny, B., \& Louman, B. (2008). Manejo forestal comunitario en América Latina: experiencias, lecciones aprendidas y retos para el futuro. Bogor, Indonesia: Center for International Forestry Research (CIFOR).

Sachs, J. (2014). The Age of Sustainable Development. New York: Columbia University Press.

Sanz Menéndez, L. (2003). Análisis de redes sociales: o cómo representar las estructuras sociales subyacentes. Apuntes de Ciencia y Tecnología, 21-29.

Schwarts, E. (2004). Informe Naciona, Perú. Roma: INRENA - FAO.

Woolcock, M. (2001). The place of social capital in understanding social and economic outcomes. Canadian Journal of Policy Research 2, 59. 